\title{
A problemática envolvendo as questões de mérito administrativo e o Poder Judiciário: uma análise do Recurso Especial 1.438-704/SE
}

rdai.com.br/ojs/index.php/rdai/article/view/154

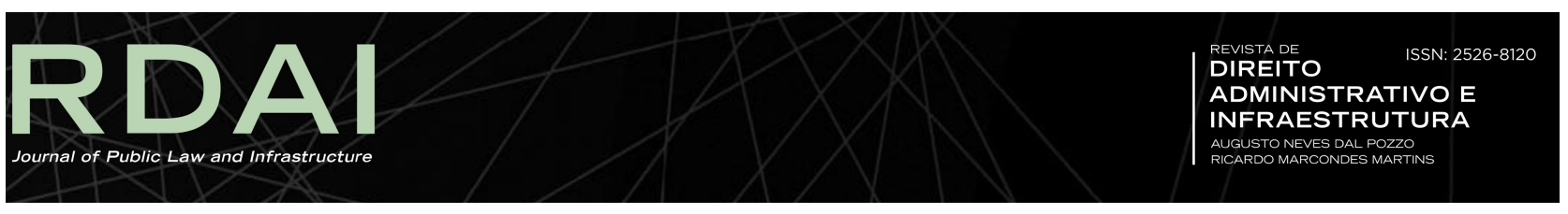

RDAI | Revista de Direito Administrativo e Infraestrutura - ISSN 2526-8120 https://doi.org/10.48143/rdai
1. Início/
2. Arquivos/
3. v. 3 n. 8 (2019)/
4. Artigos

\section{The problematic involving issues of administrative merit and the Judiciary: an analysis of the Special Appeal 1,438-704/SE}

- Alencar Frederico Margraf Universidade Estadual de Ponta Grossa (Ponta Grossa, Paraná, Brasil) https://orcid.org/0000-0001-8512-4261

- Wilson Yoshiro Oyamada Universidade Estadual de Londrina (Londrina, Paraná, Brasil)

DOI: https://doi.org/10.48143/rdai/o8.afm

Palavras-chave: Palavras-chave: Mérito administrativo - Poder Judiciário - STJ Conveniência - Oportunidade

\section{Resumo}

Nesse comentário jurisprudencial será analisada a polêmica em torno das questões de mérito administrativo e o Poder Judiciário. No caso, abordaremos a decisão do Superior Tribunal de Justiça no Recurso Especial 1.438.704/SE (2014/o042310-5). O problema, aqui apresentado, repousa sobre a (im)possibilidade de o Poder Judiciário tratar de questões de conveniência e oportunidade das decisões administrativas, conhecidas como "mérito administrativo". Analisaremos, ademais, se as decisões de mérito administrativo viola a "separação de poderes". Por oportuno, serão demonstrados alguns posicionamentos doutrinários a respeito do conceito de mérito administrativo.

\section{Downloads}

Não há dados estatísticos. 


\section{Biografia do Autor}

Alencar Frederico Margraf, Universidade Estadual de Ponta Grossa (Ponta Grossa, Paraná, Brasil)

Mestre em Ciência Jurídica pela Universidade Estadual do Norte do Paraná - UENP. Especialista em Direito Penal, Processo Penal e Criminologia pelo Instituto Busato de Ensino. Pós-Graduado lato sensu pela Escola da Magistratura do Estado do Paraná, Núcleo de Ponta Grossa. Bacharel em Direito pela Universidade Estadual de Ponta Grossa - UEPG. Membro efetivo do Instituto Paranaense de Direito Processual. Bolsista da Coordenação de Aperfeiçoamento de Pessoal de Nível Superior (maio 2013/maio 2015). Professor de Ciência Política e Teoria do Estado e de Processo Penal no Centro de Ensino Superior dos Campos Gerais (CESCAGE). Advogado e Pesquisador. alencarmargraf@yahoo.com.br

Wilson Yoshiro Oyamada, Universidade Estadual de Londrina (Londrina, Paraná, Brasil)

Mestrando em Filosofia pela Universidade Estadual de Londrina. Pós-Graduado em Filosofia Moderna e Contemporânea: aspectos éticos e políticos pela mesma instituição. Pós-Graduado em Filosofia e Direitos Humanos pela Pontifícia Universidade Católica do Paraná. Membro do Grupo de Pesquisa Teorias da Justiça. Pesquisador. oyamadawilson@gmail.com

\section{Referências}

ARISTÓTELES. A política. São Paulo: Martins Fontes, 1998.

BANDEIRA DE MELLO, Celso Antônio. Curso de direito administrativo. 18. ed. São Paulo: Malheiros Editores, 2005.

CARVALHO, Matheus. Manual de direito administrativo. 2. ed. Salvador: JusPodivm, 2015 .

MARINELA, Fernanda. Direito administrativo. 4. ed. Niterói: Impetus, 2011.

MAZZA, Alexandre. Manual de direito administrativo. 4. ed. São Paulo: Saraiva, 2014.

MEIRELLES, Hely Lopes. Direito administrativo brasileiro. São Paulo. Malheiros Editores, 2003.

MORAES, Alexandre de. Direito constitucional. 21. ed. São Paulo: Atlas, 2007.

SILVA, José Afonso da. Curso de direito constitucional positivo. São Paulo: Malheiros Editores, 2004. 


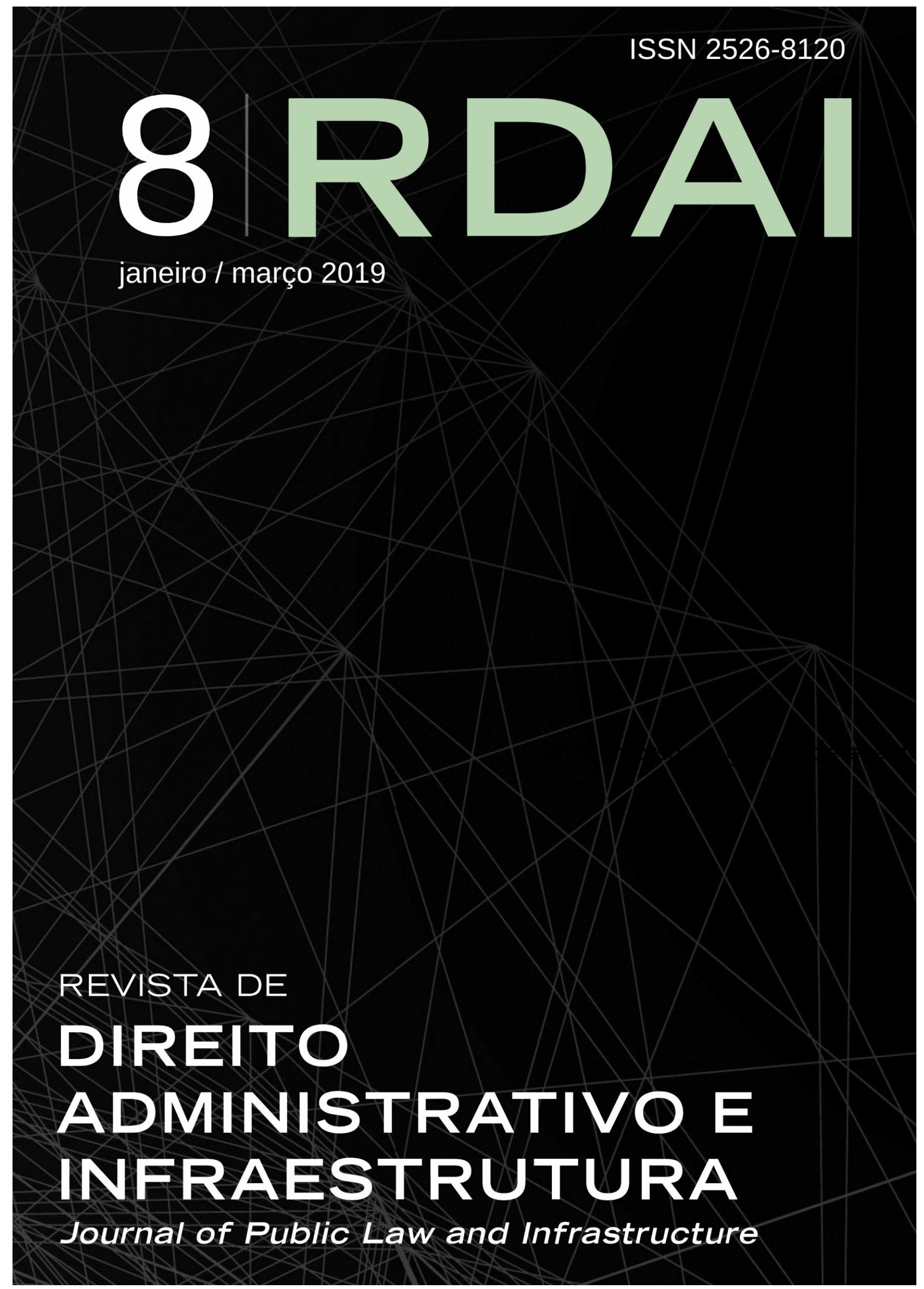

Publicado 
Edição

v. 3 n. $8(2019)$

Seção

Artigos

A submissão e a publicação de artigos são gratuitos; avaliados por pares; o periódico utiliza o CrossCheck (antiplágio) e cumpre com o Guia dos Editores da COPE - Committee on Publication Ethics, além das recomendações Elsevier e SciELO. Confira as Regras para a submissão e avaliação da RDAI. 